\title{
Relating Locke's Idea of Social Contract Theory and Political Accountability in Tanzania
}

\author{
Rogers Rugeiyamu Amani Shayo Erick Kashonda Bahati Mohamed \\ Local Government Training Institute, P.O. BOX 1125, Dodoma
}

\begin{abstract}
Locke opines that, a State is created through the medium of a contract in which each individual agrees with each other to give up to the community the natural right of enforcing the law of reason, in order that life, liberty and property may be preserved. In modern States, such contract exists in their constitutions. The constitution grants power to citizens to hold the government accountable. The aspect as to whether the Locke's idea of accountability works in Tanzania attracts an interesting debate. This article explores the mechanism (s) used in Tanzania by citizens to hold political leaders accountable basing on Locke's idea of social contract using 2010 and 2015 general elections as case study. Data were collected through reviewing documents including the constitution of Tanzania and literatures on Locke's social contract idea on political accountability. The study reveals that, it is through general elections citizens hold the government accountable hence, conforming to the said contract idea. The mechanism has its pros and cons in the country though debatably, the study opines that the cons seem to outweigh the pros. While the state moves on using the mechanism revealed, it can think of application of other mechanisms like referendum to better conform to Locke's idea of accountability in Social Contract Theory.
\end{abstract}

Keywords: Political accountability, Locke and Social Contract Theory

DOI: $10.7176 / \mathrm{JAAS} / 68-09$

Publication date:September $30^{\text {th }} 2020$

\subsection{Introduction}

The origin of the social contract theory is premised on an agreement entered into by men who originally had no governmental organisation which resulted into a State. However, to understand the essence of a contractual agreement (a social contract) which can be found in the political treatises, it is pertinent to understand that previously, the history of the world is traced from the period of Pre-Institution of the State (Freeman, 2007)

In the Pre-Institution of the State era, there was nothing like government. Hence, there was no law which could be enforced by a coercive authority. In effect, it would be apt to say men and women lived in a State of Nature, and inevitably were subject to regulations prescribed by nature because there was no human authorities to formulate these rules let alone enforcing them. A State of Nature is viewed to be the hypothetical life of people before societies (current States) came into existence. After a time lapse, a decision was reached by men for the establishment of government based on their consent to part with their liberty having agreed to obey the laws of government and in return the government to be accountable to them. The consent to part with their liberty is subject to a consensus having lived in a State of Nature without a coercive agency. In fact, the essential idea to note is that, the State is a human creation as a result of a contractual agreement between men (Mouritz, 2010).

The idea of the social contract lays the belief that, the State only exists to serve the will of the people. Arguably, people are the source of all political power enjoyed by the State governments. They can choose to give or withhold this power. This is to say, the States governments are expected to be accountable to the people, serving their interests and protecting their lives, liberties and properties (Friedmann, 1999).

The term social contract can be found in the writings of Plato and later expanded by Thomas Hobbes (15881679) through his work - Leviathan- in response to the English Civil War. The theory was further developed by other philosophers including John Locke (1632-1704) and Jean Jacques Rousseau (1712-1778) (Manzoor 2013). The focal point of this study is on the social contract idea by John Locke and how it relates with political accountability in Tanzania.

To begin with, a brief clarification of the terms social contract and accountability are explained. Then an overview of the Permanent Constitution of Tanzania 1977 with regard to accountability is provided carefully and critically highlighted. Lastly, a discussion and conclusive remarks are provided.

\subsection{Review of Locke's Idea of Social Contract}

John Locke (1632-1704) a British philosopher, Oxford academic and medical researcher, presented the idea of a social contract by firstly introducing the concept of the State of Nature. The purpose of Locke in his work titled Two Treaties of Government (1690) was to justify the English Revolution of 1688 after James II had been deposed from the throne and William was invited to occupy it (Rawls, 2007).

According to John Locke, in the State of Nature men were free and equal because each lived according to his/her own liking even though this freedom was not licensed. Locke stresses that, in the State of Nature, there was a natural law or the law of reason (the use of reason to analyses human nature in deducting binding rules of 
moral behavior via accounts of observed and posited aspects of reality of the human condition) which commanded that no one shall impair the life, the health, the freedom or the possessions of another. In other words, the law of nature of Locke stresses the freedom and preservation because there is no common superior to enforce the law of reason hence each individual is obliged to work out his own interpretation (Gaba, 2007).

The point to keep in mind is that, for Locke, while the State of Nature was not a State of chaos as Hobbes contends (About the natural condition of mankind that would exist if there was no government, no civilization, no laws and no common power to restrain human nature, life in the State of Nature was nasty, brutish and short) nevertheless, the insecurity of enjoyment of rights among men and women was presumably very evident. Essentially, his contention is that, the state or political society is instituted so as to remedy the inconveniences of the State of Nature (Penguin Books, 1993; Mouritz, 2010).

In that regard, the State, according to John Locke, is created through the medium of a contract in which each individual agrees with every other to give up to the community the natural right of enforcing the law of reason, in order that life, liberty and property may be preserved. It is therefore, significant to note that for Locke, unlike Hobbes, power resides with the community and not with the government. It must also be stressed that, the contract is not general but limited and specific so much so that the natural right of enforcing the law of reason reserved to the individual limits the just power of the community is given up (Mouritz, 2010).

Possibly, in modern States including Tanzania, the contract the Locke is talking about in Social Contract Theory can be evidenced through constitutions. The constitution establishes the government and gives it power to exercise the people's rights on behalf and in return, citizens have to respect the government as part of the contract. However, it should be born in mind that, the government power comes from the people hence, it should be accountable to them (Juma, 1996). Soundly, the relationship that exists between Locke's idea of social contract and accountability is the fact that, people agrees to give up some of their rights to be exercised by the government through a set contract and in return, the government should be answerable to people. One would debate that, the contract should set mechanism that allow people to look in to the exercising of the authority and power vested to by the government and give them power to reward it due to its actions. Here, is where the concept of political accountability come about as it is elaborated below.

\subsection{Accountability: Conceptual Review}

The concept of accountability can be viewed from several angles when trying to find out its meaning. Such angles relate to leadership, governance and political. The focal point of this study is political bearing in mind that, constitutions mostly defining such contract are political documents. However, the former two are also defined due to their significance and relevance when defining the latter.

In leadership, accountability is taken as the reaction and assumption of responsibility for actions, results, decisions, and policies including the supervision, governance, and implementation within the scope of the role or employment position and encompassing the obligation to report, explain and be answerable for resulting consequences (Williams, 2006). When relating this concept with accountability in political angle, one would argue that, political leadership is required to be responsible and make decisions on behalf, act and give expected results to citizens.

In governance, accountability has expanded beyond the basic definition of "one being called to be accounted for one's actions". It is frequently described as an account-giving relationship between individuals. For instance "A is accountable to B when A is obliged to inform B about A's actions and decisions, to justify them, and to suffer punishment in the case of eventual misconduct" (Schedler, 1999). Hither, the concept of accountability is regarded as a synonym of good governance covering various distinct concepts such as equity, democracy, responsibility, responsiveness and integrity. When connecting this concept with political accountability, it entails political leaders observing the mentioned above aspects in governance (Bovens, 2007).

In political perspective, accountability is the answerability of the government including civil servants and politicians to the public and to legislative bodies such as a congress or a parliament. The government's power can be categorized in into political and administrative albeit the focus of this study is political wing of the government due to the fact that, they are directly chosen by people into power hence, being directly responsible to them while civil servants are hired/appointed and accountable to the political process when hired (Przeworski Stokes \& Manin, 2003).

Looking at the concept of political accountability, it can be argued that, citizens have power to question political officials regarding public expenditure, issues relating to maintenance of government power and fulfilling public needs (Goetz \& Gevanta, 2001).

When discussing the angle of political accountability taking into account the contract (The constitution of the United Republic of Tanzania); two scenarios can be elaborated respectively, which is vertical and horizontal accountability. Vertical accountability refers to the methods by which the State is (or is not) held to account by citizens and when applicable Non-State agents through the relationship between citizens and their political representatives. Vertical accountability takes two forms: electoral accountability that holds leaders accountable 
through periodic elections and societal accountability denotes the more informal role of Non-State agents checking governments' powers via the media, vocal civil society organizations and popular protest. It involves lobbying, demanding explanations and threatening government with less formal sanctions (This form will not be the focus of the study due to the fact that, it does not involve people directly holding the government accountable rather in groups) (O’Donnell, 1994; Malena Forster \& Singh, 2004).

Horizontal accountability refers to the intra-governmental control mechanisms between the legislature, the executive and the judiciary and between different sub-entities of the executive, including Cabinet, line ministries and lower level administrative departments and agencies. In addition, courts and parliamentary oversight functions includes special institutions of restraint (Ombudsman) such as the auditor general, anti- corruption commissions and human rights commission (Stapenhurst \& O’Brien, 2007).

\subsection{Political Accountability on the Constitution of the United Republic of Tanzania, 1977}

In a democracy, political leadership is accountable first and foremost to the citizens who elect them. According to the Constitution of the United Republic of Tanzania of 1977, Article 8, The United Republic of Tanzania is a state which adheres to the principles of democracy and social justice and accordingly the sovereignty resides in the people and it is from the people that the government through this constitution derives all its power and authority. The primary objective of the government is the welfare of the people. The government shall be accountable to the people and the people shall participate in the affairs of their government in accordance with the provisions of the constitution.

One would argue that, for Tanzania, accountability means the government answerability to the people as it is from them it derives its power and authority. In this regard, the constitution sets the mechanisms through which the people can make the government answerable to them.

When it comes to vertical accountability which is the center of discussion as it involves citizens directly to the process, the constitution of the United Republic of Tanzania grants this type to take place after five years during general elections. With this statement, accountability of political leadership to citizens take place after five years. During election, it is when citizens can hold political leaders accountable of their actions by deciding to vote for or against them. This can be evidenced in the constitution of the United Republic of Tanzania through two scenarios; one, is election of the Members of Parliament and two, the President. Regarding the first scenario, the constitution shows that, the life of the Parliament of the United Republic of Tanzania is five years as shown in Article 65 (1) which states that; "subject to the provisions of this constitution, the life of each parliament shall be five years."

The constitution goes further on the aspect of the tenure of members of parliament by elaborating more about the reasons which may cause a member of parliament to cease to be a member upon occurrence of several reasons as mentioned in Article 71 (1) (a to g). Such reasons include if, anything happens which, had he not been a member of parliament, would have disqualified him from election, or would make him lose the qualifications for election, or would disqualify him from election or appointment in accordance with the provisions of this constitution, where such member of parliament is elected president, where a member of parliament fails to attend three consecutive meetings of the National Assembly without the permission of the Speaker; where it is established that he has contravened the provisions of the law concerning the ethics of public leaders; where a member of parliament ceases to be a member of the party to which he belonged when he was elected or appointed to be a member of parliament, where a member of parliament is elected or appointed Vice President and lastly, in the case of a member of parliament who is required to submit a formal statement of property in accordance with the provisions of Article 70 fails to do so. Debatably, among the matters mentioned above, none gives power to citizens directly to remove a member of parliament from power other than through election.

On the second scenario, Article 42 (2) elaborates that, the President shall assume office for a period of five years after being elected. It states that "the president shall subject to sub-article (3), hold office for a period of five years from the date on which he was elected. "In that sense, citizens can hold the President accountable only in the ballot paper and not otherwise. This type of accountability takes place after five years as Article 42 of the constitution of the United Republic of Tanzania stipulates.

Notwithstanding the provisions of Article 46 of the constitution, the National Assembly may pass a resolution to remove the president from office if a motion to impeach the president is moved and passed in accordance with the provisions of the Article. However, no motion to impeach the president shall be moved unless if it is alleged that the president has committed acts which generally violate constitution or law concerning ethics of public leaders. This proves that, holding the president accountability by citizens is also through election only leaving aside the assistance they might get from representatives.

The horizontal accountability though won't be the center of discussion but for sake of cementing the study it is significant. It involves intra-governmental control mechanisms and can also be observed in the constitution. The constitution of the United Republic of Tanzania provides for this aspect of accountability through the Public Leader's Ethics Secretariat as provided in article 132 of the constitution which prohibits conduct and behavior of 
the public servants. Behaviors like dishonest, favoritism or lacks of integrity, or which tends to promote or encourage corrupt practices in public affairs or jeopardizes public interest or welfare; rules which prescribe penalties which may be imposed for breaches of the code of ethics; and provide for procedure, powers and practice to be applied in order to ensure compliance with the code of ethics; and other provisions necessary for the purpose of promoting and maintaining honesty, transparency, impartiality and integrity in the conduct of public affairs and for the protection of public funds and any other public property, thus any leader can be held accountable if found to have committed such conduct and behavior. The constitution also establishes Prevention and Combating Corruption Bureau (PCCB) to deal with corruption misconducts in the public service.

Furthermore, the constitution provides the power to the branches of the government (Executive, Legislature and Judiciary) to hold one another accountable. The parliament is vested with power to impeach the president as stated in Article 46A. The president also can dissolve the parliament as stated in article 90 and the judiciary can hold the parliament and the executive (president) accountable due to the vested power of its establishment in article $107 \mathrm{~A}$ and $\mathrm{B}$ of the constitution of the United Republic of Tanzania.

\subsection{Methodological Issues \\ 4.1 Study Design}

This study applied a case study design. Case study entails an in depth study of a particular situation rather than a sweeping statistical survey. It is a method used to narrow down a very broad field of research into one easily researchable topic. The design is also useful in testing whether proposed theories or models work in the real world (Shuttleworth, 2008). The design added value to the study as it helped to study in depth political accountability in Tanzania and by testing the relevance of Locke's idea of Social Contract Theory in Tanzania political accountability. It also enriched the study as it allowed application of 2010 and 2015 general elections as a case to assess the effectiveness of elections in Tanzania.

\subsection{Data Collection Methods}

Data for this study were gathered through literature and document review. These are qualitative data collection methods in which documents are interpreted by the researcher to give meaning around assessment of the topic (Bowen, 2009). The study relied on monographs on social contract theory, election reports, constitution of the United Republic of Tanzania and books on political accountability. The use of such methods helped the study to provide confluence of evidence that breeds credibility.

\subsection{Data Analysis}

The study data were analysed through content analysis. Content analysis is a rule guided method used to analyse the informational contents of textual data (Marrying, 2000). The analysis was executed by defining the study problem, deciding what source of materials will be, identifying the categories focused by the study, sampling documents defined and measuring the occurrence of the pre-established categories. The method helped group collected data into categories and interpretation of its meanings to find out the relationship between accountability from Locke idea of social contract theory and political accountability in Tanzania.

\subsection{Results and Discussion}

Locke's idea of social contract unveils that, people surrender some of their sovereignties to one institution (the government) and in turn the government has to take care of its people including protecting them from any arbitrary actions. If the government fails to do that, people have power to question and applicably revolt the government. This is the idea of accountability that is being referred to in this study.

Arguably, social contract from Locke's perspective can be said to exist in Tanzania and the mechanism for holding political leaders accountability are set. The United Republic of Tanzania through its constitution of 1977 , the major mechanism through which citizens can hold the political leadership accountable is through general elections (vertical accountability). As revealed above, elections take place after every five years for members of parliament as stated in article 65 and president in article 42 (2). Every citizen who have attained the age of 18 years is entitled to vote under article 5 (1) of the constitution of the United Republic of Tanzania. During elections, it is when citizens get the chance directly to hold political leaders accountability through the ballot paper. Political leaders will have to report to citizens of how well they performed and pushed citizens' development agenda for the past five years. Here, citizens get chance to punish or reward political leaders due to their performance during the past five years of their being into power. Citizens can opt to continue with such leadership or change it. This proves how the power of the government is said to emanate from people as Locke contends. Perhaps, those who performed well are likely to be re-elected and vice versa will be true for those poor performers according citizens' perspectives.

This is enough for one to reason that, theoretically, Tanzania observes the Locke idea of social contract. Such reasoning comes from the fact that, the source of power of the government is vested to Tanzania citizens. 
According to the constitution, the government have to work for the interest of people and protect their life, liberty and property. The constitution hence, provides power for the people to hold the government accountable, if the public smells elements of breaching the contract. The given power is through elections (Provided under Article 5 of the constitution) which is conducted after every five years. The idea of making the government come and go after five years is to ensure that people can have a chance to hold it accountable and remind it that it is people who own the state and its power.

However, what does political accountability means for Tanzania and how far the accountability mechanism (election) used is effective as far as Locke's idea of social contract is concerned? To answer these questions, the study honestly, assessed 2010 and 2015 general elections as a case to find out their effectiveness, to identify the pro and cons this mechanism and then weighing them.

\subsection{Effectiveness of Elections in Tanzania: A case of 2010 \& 2015 General Elections}

Three factors can be considered in evaluating the effectiveness of elections in Tanzania as a mechanism used by citizens to hold political leaders accountability including; one, the voters turnout for presidential elections, two, political party winning dominance and three, the pace of re-election of members of parliament for the case of selected constituencies as below.

\subsubsection{Voters Turnout for Presidential Elections}

The voters' turnout for 2010 presidential general election was $42 \%$ of the total registered voters. For 2015 general election, the voters' turnout was $67 \%$ of the total registered voters, which means $48 \%$ and $32.7 \%$ did not get chance to vote for 2010 and 2015 elections respectively (COMMON WEALTH, 2010; National Electoral Commission, 2016). If one take 2015 elections alone, despite the improvement of the voters turnout compared to 2010, the turnout is not that much effective due to the fact that more than seven million citizens did not get chance to vote out of twenty three millions eligible. This is a huge number when it comes to accountability hence raising skepticism about its effectiveness. Additionally, in all of the said elections, the Chama Cha Mapinduzi (CCM) candidate's won elections. Data on the voters' turnout are given in table 1.

Table 1: Voters' Turnout for Presidential Election for 2010 and 2015

\begin{tabular}{|c|c|c|c|}
\hline Election Year & Voters Registered & $\begin{array}{c}\text { Turnout } \\
\mathbf{5 \% 5}\end{array}$ & Discrepancy (\%) \\
\hline 2010 & $20,137,303$ & $8,626,283$ & $11,511,020$ \\
& & $(42 \%)$ & $(58 \%)$ \\
\hline 2015 & $23,161,440$ & $15,596,110$ & $7,565,330$ \\
& & $(67.34 \%)$ & $(32.7 \%)$ \\
\hline
\end{tabular}

Source: Tanzania Election Monitoring Committee (2016); COMMON WEALTH (2010; 2015); National Electoral Commission (2016)

\subsubsection{The Political Parties Wining dominance for Parliamentary Elections}

For both the 2010 and 2015 general elections, the Chama Cha Mapinduzi (CCM) dominated election results (TEMCO, 2011; National Electoral Commission, 2016). In 2010, the party won by $77.8 \%$ and nearly $74 \%$ in 2015 as tables 2 and 3 show. In this regard, four ideas come in mind when one look at the CCM dominance. One is that, the party have managed to do what citizens intended to be done in terms of development; second, other parties have failed to convince citizens to be elected; Three, if dominance is used as a factor to measure accountability, then CCM leaders are accountable to the people as it has been dominating in the selected elections; and four, if party winning dominance is used as an indicator of low political accountability, then, the contention might be still there is low political accountability in Tanzania. One would question these assumptions especially if the process of election is studied in assessing its transparency. Hence, the study recommends studies to be done on how the election process (transparency) affects political accountability.

Regarding the voters turnout, still not all citizens got the chance to participate in both general elections studied. If you take the voters turnout for the presidential elections as base and then assume that, those participated in presidential elections also participated in parliamentary elections, hence, not all citizens got the chance to hold members of parliament accountability. 
Table 2: Results for 2010 Parliamentary Election for each Political Party

\begin{tabular}{|l|c|c|c|}
\hline No. & Name of a political party & Seats acquired & Percentage (\%) \\
\hline 1 & CCM & 186 & 77.8 \\
\hline 2 & CHADEMA & 23 & 9.6 \\
\hline 3 & CUF & 24 & 10.0 \\
\hline 4 & TLP & 1 & 0.4 \\
\hline 5. & NCCR- Mageuzi & 4 & 1.8 \\
\hline 6. & UDP & 1 & 0.4 \\
\hline \multicolumn{2}{|c|}{ Total } & $\mathbf{2 3 9}$ & $\mathbf{1 0 0}$ \\
\hline
\end{tabular}

Source: TEMCO (2011)

Graph 1: Political Parties Distribution of Parliamentary Seats

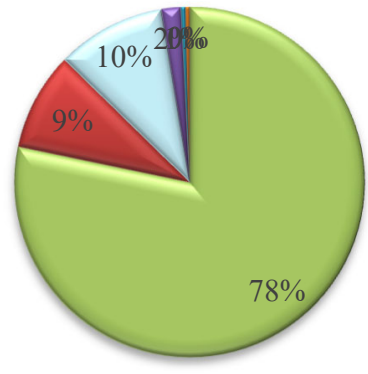

$\square C C M \square C H A D E M A \quad \square C U F \quad \square N C C R-M a g e u z i \quad \square T L P \quad \square U D P$

\section{Results for 2015 Parliamentary Election for each Political Party}

Table 3: Results for 2015 Parliamentary Election for each Political Party

\begin{tabular}{|l|c|c|c|}
\hline No. & Name of a political party & Seats acquired & Percentage (\%) \\
\hline 1 & ACT- Wazalendo & 1 & 0.38 \\
\hline 2 & CCM & 195 & 73.86 \\
\hline 3 & CHADEMA & 35 & 13.26 \\
\hline 4 & CUF & 32 & 12.12 \\
\hline 5. & NCCR- Mageuzi & 1 & 0.38 \\
\hline \multicolumn{2}{r|}{ Total } & $\mathbf{2 6 4}$ & $\mathbf{1 0 0}$ \\
\hline
\end{tabular}

Source: NEC report (2016)

Graph 1: Distribution for 2015 Parliamentary Election for each Political Party

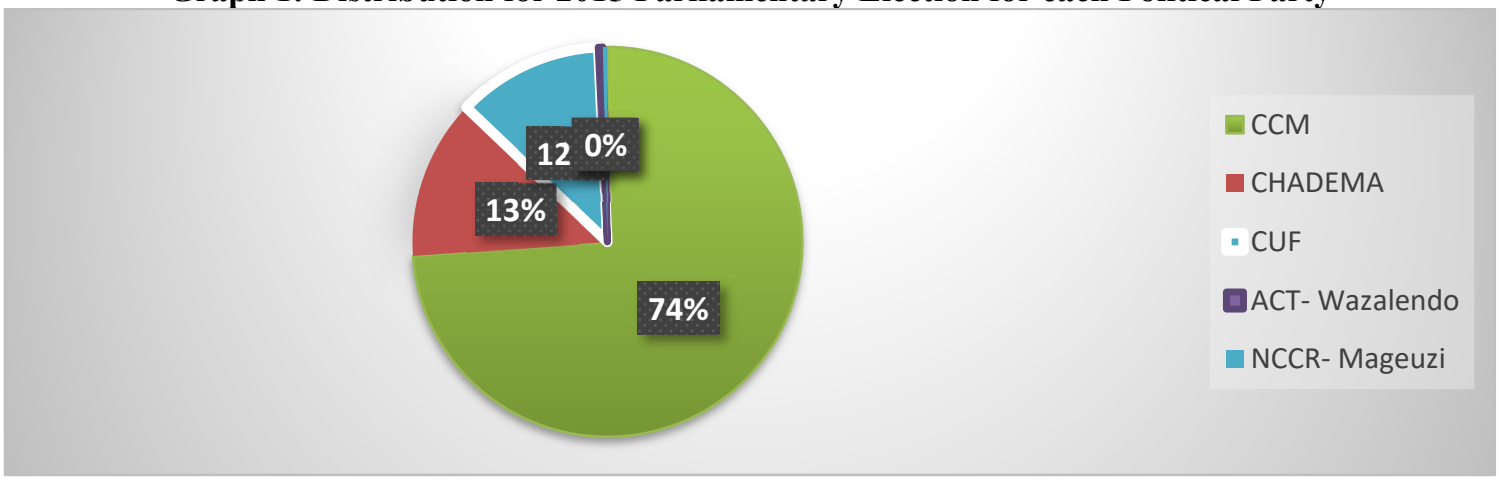

Source: NEC (2016)

5.1.3 Party Re-elections for the Same Constituency

Based on the data collected from thirty selected constituencies, a slight rotation is noted among political parties from the same constituency. For instance, you will find some of the constituencies that were dominated by CCM or CHADEMA in 2010, the same party dominated also in 2015. There are few cases for parties' rotation in same constituency as table 4 shows. A lot of assumptions can be grasped from this situation. One, when the rotation of political parties in same constituency is used as indicator of political accountability, then impliedly one would 
argue that, political accountability in Tanzania is still low. Second, if the revealed slight rotation (dominant reelection) of the same political party from the same constituency, one would argue that, citizens accept the doings of a political party in terms of solving their problems and upholding their interests hence accountable that is why it is re-elected. Third, if one leaves aside dominancy of re-election for the same political party in one constituency, and focus on a candidate (candidates are appointed for a particular political party), there has been high re-election of the same candidates for the selected constituencies and few rotation of candidates from the same political party. Hence, if one takes rotation of candidates from the same political party as an indicator of political accountability, would argue that, still, there is low political accountability.

Political parties are political institutions sponsoring candidates to become political leaders and form the government, debatably, they are also answerable to the people. Based on the assumptions revealed above, political accountability entails political parties accountability to voters as they can be removed it from power if they do not uphold their interests. With slight removal and rotation one would argue that, it is an indicator of low political accountability. However, this aspect still remains inconclusive due to the fact that, Tanzania has its own political identity and conduct which might carry the political nature of citizens holding political parties accountable. Again, this open room for further studies on the political parties' behavior and conducts, constituency rotations and their relationships with political accountability.

Table 4: Party Re-election for the Same Constituency

\begin{tabular}{|c|c|c|c|}
\hline \multirow{2}{*}{ No. } & Constituency & \multicolumn{2}{|c|}{ The Won Party } \\
\cline { 2 - 4 } & & $\mathbf{2 0 1 0}$ & 2015 \\
\hline 1. & Arusha Mjini & CHADEMA & CHADEMA \\
\hline 2. & Monduli & CCM & CHADEMA \\
\hline 3. & Kawe & CCM & CHADEMA \\
\hline 4. & CCM & CCM \\
\hline 5. & Ubungo & CHADEMA & CHADEMA \\
\hline 6. & Bumbuli & CHADEMA & CHADEMA \\
\hline 7. & Iringa Mjini & CCM & CCM \\
\hline 8. & Kalenga & CCM & CCM \\
\hline 9. & Dodoma Mjini & CCM & CCM \\
\hline 10. & Kondoa & CCM & CCT- Wazalendo \\
\hline 11. & Kigoma mjini & CCM & CCM \\
\hline 12. & Bariadi & CHADEMA & CCM \\
\hline 13. & Kigoma Kaskazini & TLP & CHADEMA \\
\hline 14. & Hai & CHADEMA & CHADEMA \\
\hline 15. & Vunjo & CCM & CCM \\
\hline 16. & Siha & CCM & CCM \\
\hline 17. & Lushoto & CCM & CCM \\
\hline 18. & Korogwe & CHADEMA & CHADEMA \\
\hline 19. & Mwibara & CCM & CCM \\
\hline 20. & Mbeya Mjini & CCM & CCM \\
\hline 21. & Bukoba Vijini & CCM & CCM \\
\hline 22. & Kongwa & CCM & CCM \\
\hline 23. & Nzega & CCM & CHADEMA \\
\hline 24. & Chato & CCM & CCM \\
\hline 25. & Kisarawe & CCM & CCM \\
\hline 26. & Ngara & CCM & CCM \\
\hline 27. & Nkenge & & CCM \\
\hline 28. & Bukoba Mjini & \\
\hline 29. & Bukoba Vijijini & Kongwa & \\
\hline 30 & & & CHADEMA \\
\hline
\end{tabular}

Source: NEC $(2011,2016)$.

Cementing the discussion on the data revealed above, for satisfied assessment of the effectiveness of elections as a method used by citizens to hold political leaders accountable, the study also went through to identify the advantages and disadvantages of it as far as political accountability is concerned as below.

\subsubsection{Pro of the Accountability Mechanism}

This type of accountability (elections) gives citizens a chance to vote a political leader they see fit for the post. Here through ballot papers, citizens will reward those they think will help them in the future of five years. Citizens expect to move from the condition they are to the highest one (development) resulting from the good allocation of 
resources done by the government. This is due to the fact, political leaders are vested with power to allocate resources on behalf of them. Hence, citizens will have the chance to vote for a person they think will serve their best interest. This is a good thing as people will have a chance to question how their preferences will be fulfilled by candidates.

Again, through election, citizens have power to remove unfaithful leaders in the public service. In this argument, citizens have power not to vote for person who is seen to act against the public service ethics like being involved in corruption, favouritism and inefficiency. Also, in the view of citizens, political leaders who do not care about public interest can be voted against during election.

The mechanism saves the political costs; the state incurs election costs once for every five years. This saves the cost of conducting elections let say every year. In this regard, instead of using huge funds in the election process, the solicited funds is being allocated for citizens' development and not thinking or conducting of election every time or every year.

\subsubsection{Cons of the Accountability Mechanism}

Despite the fact that it is the only mechanism used directly by citizens to hold political leaders accountable, it takes place only after five years. In between five years, citizens have no power of holding the political leader accountable. Unfaithful political leaders can use this chance to misuse the public resources or make poor decisions. This is due to the fact that, they are aware that they cannot easily be removed by citizens until the period of five years is completed. In that sense, the mechanism proves not to be effective as it limits the power of citizens to hold political leaders accountability before next election.

Unfaithful leaders may hide themselves at the expense of political parties hence re-elected again into power. Government by political party is a common practice in Tanzania and the world at large. Political leaders are sponsored by political parties. For the sake of Tanzania, the voting is for a political party, which is to say, despite the fact that the choice can be done due to citizens' preference to candidates, but should represent a political party. In that sense, through dirty political games such as corruption and economic power, a person (unfaithful) can manipulate to become a candidate to represent a certain political party and be re-elected. For example, the TEMCO newsletter, no. 1 of 2010a reported that, despite the introduction of the Election Expenses Act No. 6 of 2010, and in spite of the early deployment of TAKUKURU the anti-corruption special unit to monitor and prevent corruption in the ongoing political process, observers noted and reported a wide of corruption practices. Another example is that, the Daily News of 27 July 2010 reported that 17 suspects were arrested by the PCCB (TAKUKURU) in Kilimanjaro while bribing members of a certain political party (Makulilo \& Raphael, 2010). Due to such manipulations, the idea of holding political leaders accountability becomes weak.

Again, not all citizens get the chance to participate in election. Due to several circumstances relating to legal provisions, climatic conditions and failures to register in the voter's registration book, not all citizens eligible for voting will have a chance to hold political leaders accountability. Here, the skepticism is whether the elected leaders are representing the interests of the whole citizens. Despite the fact that, Tanzania practices simple majoritarian system whereby the winner take all votes, the question has been if the winner is being held accountable by all citizens. The findings in table 1 show, in 2010 the voters' turnout was $42 \%$ and in 2015 it was $67.3 \%$. Despite the increase in percentage but the turnout is still a challenge.

Moreover, considering its weaknesses and due to the fact that election is the only mechanism that is used, it gives the room for political leaders not to take seriously citizens interests. When some political leaders realizes that they cannot be removed by citizens easily in power after being elected, there are possibilities that they can use that chance to serve their own interests first and leaving aside citizens demands.

\subsubsection{Weighing the Pros and Cons}

If one look closely to pro, would realize that people have chance to vote for the government and hold it accountable. It also works in favor of the government as it saves cost since elections takes place after five every years, hence, not conducting election let say every year. However, the cons prove that not all people participates in elections, unfaithful leaders using that chance to misuse power, politicians using preferences of political parties to manipulate citizens and being the only mechanism used.

Again, when assessing the findings, not all citizens get the chance to participate in elections, one political party dominating elections and the slight rotations in the same constituency says a lot on hardships of accountability.

Weighing both sides, it is the opinion of this study that, cons affects much citizens as far as the idea of political accountability is concerned. Since it is the only mechanism and putting into consideration of the weaknesses observed likely it won't be fully effective. If there could be other mechanism, let say using referendum (a direct and universal vote in which an entire electorate is invited to vote on a particular proposal/ removal of the leader before the official term has ended) to the members of parliament, it could have been good for the sake of ensuring people have full power to hold their leaders accountable. 


\subsection{Conclusion}

There is a relationship between Locke's idea of social contract and political accountability in Tanzania. The existing relations is seen on the power of elections vested to citizens when holding political leaders accountability. Elections as a social contract mechanism has proven to face some challenges attributed by the youngness of the country in practicing it. However, the mechanism should be maintained though requiring fully cementation and improvements to ensure that citizens enjoy their rights when holding political leaders accountability.

\subsection{Way Forward}

Weaknesses of elections as a mechanism used by citizens to hold political leaders accountable discussed above should be addressed. In this aspect, education on significances of election should be strengthened to increase the voters' turnout. Strengthening political institutions such as political parties to ensure that, they do not produce unfaithful leaders. Again, the recall referendum mechanism can be thought to be used as way of strengthening the process of accountability in place. It can be used to hold accountable members of parliament. It can be done by voters signing a petition to remove a leader. This mechanism is practiced in Canada, Bavaria, Peru, United States of America etc. Moreover, citizens should be made aware that they have a contract with the government and it have to work on behalf of them and in return they have to respect and question it wherever possible.

\section{References}

Bovens, Mark. (2007). Analysing and assessing accountability: a conceptual framework. European Law Journal. 13(4):447-468. DOI: http://dx.doi.org/ 10.1111/j.1468-0386.2007.00378.x

Bowen, G. A. (2009). Document analysis as a qualitative method. Qualitative Research Journal. 9(2): 27-40.

Commonwealth Observer Group. (2015). Tanzania general elections $25^{\text {th }}$ October 2015. 1-58.

Freeman, Samuel, (2007a). Justice and the Social Contract. Oxford: Oxford University Press.

Friedmann, W. (1999). Legal theory. Universal Law Publishing CO. LTD, India.

Gaba, Jeffrety M. 2007. John Locke and the meaning of the takings clause. Missouri Law Review. 72 (2): 1-55.

Goetz, Anne M. and Gaventa, John. (2001). Bringing citizen voice and Client Focus into Service Delivery. Brighton: University of Sussex.

Internet encyclopedia of philosophy. (2015). Social Contract. Retrieved on 16th April 2020, from http://www.iep.utm.edu/soc-cont/\#SH2b

Juma, Ibrahim H. (1996). "Constitutional-Making in Tanzania: The Case for a National Conference" In. Law and the Struggle for Democracy In East Africa, ed. Oloka-Onyango, J Kibwana, K and Peter, C M, Nairobi. Claripress.

Kelly, Martin. (2019). Social Contract. Retrieved on 16th April 2020, from http://americanhistory.about.com/od/usconstitution/g/social contract.htm.

Locke, John. (1993). Second Treatise of Government in John Locke, Political Writings (Penguin Books, 1993).

Makulilo, Alexander and Raphael, Consolata. (2010). The October 2010 general elections in Tanzania. Department of Political Science \& Public Administration, University of Dar es Salaam. 1-15.

Malena, Carmen Forster, Reiner and Singh, Janmejay. (2004). Social accountability: an introduction to the concept and emerging practice. World Bank Social Development Papers, no.76. Washington DC: World Bank.

Manzoor, Laskar. (2013). Summary of Social Contract Theory by Hobbes, Locke and Rousseau. Available at SSRN: https://ssrn.com/abstract=2410525 or http://dx.doi.org/10.2139/ssrn.2410525.

Marrying, Ph. (2000). Qualitative content analysis. Qualitative Social Research. 1(2): 20.

Mouritz, Thomas. 2010. Comparing the social contracts of Hobbes and Locke. The Western Australian Jurist. 1(1): 123-127.

Mtulya, Athuman. (2015). Muhongo Quits over Escorow Scam. Dar-es- Salam: The Citizen.

National Electoral Commission. (2011). Commission report on presidential, members of parliaments and councilors elections of 2010. The states's chief printer. Dar e salaam, Tanzania.

National Electoral Commission. (2016). Commission report on presidential, members of parliaments and councilors elections of 2015. The states's chief printer. Dar e salaam, Tanzania. 1-90.

O’Donnell, Guillermo. (1994). Delegative Democracy. Journal of Democracy. 5(1): 55-69. DOI: http://dx.doi.org/ 10.1353/jod.1994.0010.

Przeworski, Adam Stokes, Susan C and Manin, Benard. (2003). Democracy, accountability, and representation. Cambridge University Press.

Rawls, John. (2007). Lectures on the History of Political Philosophy. Harvard University Press.

Schedler, Andreas. (1999). "Conceptualizing Accountability". In The Self-Restraining State: Power and Accountability in New Democracies, ed. Schedler, Larry, Andreas Diamond and Plattner, Marc F, 13-28 London: Lynne Rienner Publishers.

Shuttleworth, M. (2008). Case Study Research Design. Retrieved Jun 23, 2020 from Explorable.com: https://explorable.com/case-study-research-design. 
Stanford encyclopedia of philosophy. (2001). John Locke. Retrieved on 16th April 2015, from http://plato.stanford.edu/entries/locke/\#SocConThe.

Stapenhurst, Rick and O'Brien, Mitchell. (2007). Accountability in governance. World Bank Institute Research Note. Washington DC: World Bank.

TEMCO. (2011). The report of 2010 Tanzania general elections. 95-103.

TEMCO. (2016). Report on the 2015 elections in Tanzania. 1-199.

United Republic of Tanzania. 1977. The constitution of the united republic of Tanzania. Dar-es-salaam: Government Publisher.

Williams, Christopher. (2006). Leadership accountability in a globalizing world. London: Palgrave Macmillan. 